\title{
The Relationship between Love of Money, Islamic Religiosity and Life Satisfaction: A Muslim's Perspective
}

\author{
Arif Hoetoro \\ Brawijaya University \\ hoetoro@ub.ac.id
}

\begin{abstract}
This research scrutinizes the relationship between Love of Money (LOM), hedonic behavior and Islamic religiosity in pursuing life satisfaction in consumption. By utilizing accidental sampling method, the research then employed 99 customers who spent their money in one of the biggest department stores in Malang City. The calculation of data with SmartPLS-3.1.8 revealed that Islamic religiosity significantly affects live satisfaction $(\beta=0.290 ; \rho$-value $=0.003)$. In the same time, LOM significantly influences hedonic behavior $(\beta=0.417 ; \rho$-value $=0.000)$. However, hedonic behavior does not mediate the relationship between LOM and life satisfaction. This study accordingly concludes that Islamic religiosity plays a main role in consumption. Therefore, it is suggested that every Muslim have to instill Islamic religiosity in daily activities for obtaining life satisfaction.
\end{abstract}

Keywords: LOM, Hedonic behavior, Islamic religiosity, Life satisfaction

\section{INTRODUCTION}

Neoclassical economics emphasizes self-interest in guiding individuals to act rationally as had been taught in Bentham's hedonism philosophy. It was said that a motive in human's actions was substantially nothing more than pleasure and pain (Mondal, 2016). A rational man has been assumed to choose personal enjoyment as his own desire and avoid misery. In many ways, this is also associated with love of money (LOM) which sometimes leads some people to satisfy their greed (Kirchgassner, 2014).

LOM mostly represents individual's desire in achieving life satisfaction. This motive can be the main motivator and even a "frame of reference" for daily life (Tang, Tang, and Luna-Arocas, 2005). Large companies, for instance, always use money to attract and motivate employees in achieving company objectives. Therefore, it is natural if the workers always demand better wages in line with their productivity (Frakt and Piper, 2014; Krugman and Wells, 2008).

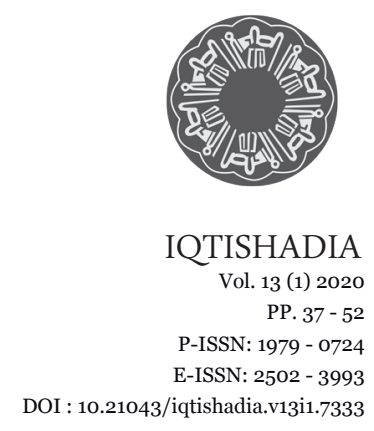


IQTISHADIA

13,1 and the goodness of life in the hereafter and keep us from the torments of hell" (Al-Baqarah [2]: 201).

Thus, every Muslim should believe that the presence of Islamic religiosity becomes an important factor and influences this hedonic tendency. However, the measurement of Islamic religiosity is very diverse. Khraim (2010) made the scale of Islamic religiosity related to the consumption patterns. Abou-Youssef et al. (2011) determined the diversity on the dimensions of experience, spiritual, intellectual, and commitment. Whereas Mahdzan et al. (2017) measured Islamic religiosity from faith, virtue, obligation, and choice. Other studies also measured Islamic religiosity according to different contexts (Spierings, 2019; Olufadi, 2016; Dasti and Siswat, 2014; and Khan, 2014).

This study examined more deeply the influence of Islamic religiosity to the relationship between LOM and life satisfaction. Agap in literatures showed a fact that people only hunt for their material satisfaction in life. In line with materialism philosophy, people think about that there is no room for other qualities except material. This research wants to fill the gap by introducing spiritual satisfaction in life when people performs Islamic religiosity. This study also investigates whether hedonic behavior can be a mediator for the relationship between LOM and life satisfaction or not. By taking the samples from consumers in one of the biggest department stores in Malang City, this research then is expected to reveal the effect of Islamic religiosity to life satisfaction and the function of hedonic behavior in mediating LOM and life satisfaction.

The paper is initiated by introduction which is presenting the background and objective of study. Second, literature review provides some theoretical basis of the variables used in this study. Third, research method explains the sample and tools in analyzing the research problem. Fourth, the results of research and its discussion. In the last section, research conclusion and recommendation will be presented. 


\section{LITERATURE REVIEW}

\section{Love of Money (LOM) and Hedonic Behavior}

Money has a high appeal and captivates everyone. In order to get money, people are willing to work hard (Tang and Liu, 2012; Akande, 2006). Business people also have the same goal when they pursue high profits by accumulating corporate and personal wealth (Tang, Tillery, Lazarevski, and Luna-Arocas, 2004). LOM thus becomes a self-desire that influences ethical behavior of an individual.

Tang et al. (2005) figured the patterns of one's behavior towards wealth by referring to personal's love of money. Individuals then perceive that money in the same time plays the role as a love and a greed. Therefore, Tang (2007) insisted that money relates to someone's subjective happiness.

The concept of LOM refers to desirable organizational behaviors such as the high levels of job satisfaction and low employee turnover rates. Theoretically, LOM was closely related to the concept of "greed" and commonly becomes a motivation that lead to unethical behavior (Tang and Jia-Chen, 2008). People who urge to get rich are always motivated to accumulate money, and see money as important (Tang and Liu, 2012). This attitude may lead to egoistic behavior (Gasiorowska and Helka, 2012) and shopping habits for pleasure (Kaul, 2007).

People love money because they want happiness. Chitchai et al. (2018) stated that money has a close relationship between person's socio-economic conditions and the happiness that they expect. To some extent, it may direct to hedonic behavior. Yilmaz and Kocoglu (2018) pointed out that hedonic behavior initially refers to a valuation over consumption which is perceived as a pleasure. This behavior has accelerated modernity atmosphere into highly hedonic lifestyles (Firat, 2013), forms a consumerist society (Yener et al., 2014), and often refers to monetary greed (Soper, 2017). In department stores, for instance, people hunt all desires and spend their money which are often impulsively (Gultekin and Ozer, 2012). Especially for young people, the shopping habits drive them to pursue satisfaction which is characterized by hedonic desire not only utilitarian one (Basaran and Buyukyilmaz, 2015).

In order to measure hedonic behavior, Borges et al. (2016) identified items of hedonism in eighteen Asian, European and American countries. Kaczmarek (2017) measures hedonic motives in behavior. Meanwhile, Ksendzova et al. (2015) made measurements and differences between individuals in assessing hedonism for their behavior.
The Relationship

between Love of Money

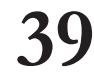


IQTISHADIA

13,1

40

Contrary to hedonism, some people might be self-limiting. In consumption, for example, people should not shop tertiary commodities before their primary needs are fulfilled. This simple behavior prevents them from the reckless use of assets. Al-Quran al-Karim emphasizes: “... and do not use (your wealth) wastefully. Surely people who are spender are Satan's brothers....." (Q.S. Al-Isra [17]: 26-27). Therefore, many actions to direct LOM properly are good behaviors, such as; money for sadaqah, good deeds and religious struggles. Conversely, excessive LOM can lead to deep regret. Al-Quran al-Karim expresses the regret of those who died because they were reluctant to provide charity: "And give a part of what we have given you before death comes to one of you; then he said (regretting): "O my Lord, if you are pleased to postpone my (death) a little more time, then I can give alms and I will be among those who are righteous" (Q.S. Al-Munfiqun [63]: 10).

\section{Islamic Religiosity}

Islamic religiosity reflects the practice of a Muslim in his daily life. It reflects beliefs, rituals, devotion, experience, manner and knowledge. Zubairu et al. (2017) asserted that religiosity and moral competence cannot be separated. In consumption behavior, Islamic religiosity often becomes a controlling factor that direct a consumer to spend money properly. For example, Aliman et al. (2018) pointed out that Islamic religiosity affects the decision making of shopping behavior among young people in Malaysia.

Therefore, measuring the level of religiosity for Muslim's life is very complex. All of his daily behaviors should reflect this religiosity. Islam is the way of life not just a rule of ritual (Faruqi, 2007) and in line with the times (Lamido, 2016). Some indicators of Islamic religiosity might be categorized as believe and ethics. This categorization does not mean that they can be separated, but it has to be combined as Muslim's behavior. Thus, the measurement of Islamic religiosity needs to be adjusted to the context.

In relation to hedonism, Islamic religiosity appears from simple consumption patterns. Religious consumers tend to be less materialistic and hence influence to avoid hedonic behavior (Joshanloo, 2013). Within this view, Islamic religiosity might be measured. Abdullah and Abdul Majid (2003) made some indicators of Islamic religiosity in consumption by limiting it to what was required and mandated. Based on the criteria, consumption must be fitted to three rules namely fard (obligatory), sunnah (commended), and haram (prohibited). 
Furthermore, Alam et al. (2011) specified that Islamic religiosity in consumption must satisfy six qualities. First, every Muslim should direct his/her consumption to an efficient life. It means that every muslim has to consume in proper manner without wasting any resources. Second is not to consume illicit goods. Islam has forbidden some goods to be consumed such as liqueur, pork, something that is illegally obtained and other haram goods. Third is consuming goods moderately. It means that every muslim is forbidden to consume excessively since Islam called it as the brothers of satan. Fourth is not to consump goods simply to achieve satisfaction but for higher goals and values. Islam has emphasized that consumption must be intended to achieve barakah, that is Allah's favor in the worldly life and the hereafter. Fifth is prioritizing more important preferences. And sixth is prioritizing meeting basic needs, and overall utility of goods and services.

\section{Life Satisfaction in Islamic Perspective}

Kainulainen et al. (2018) defined life satisfaction as "the overall evaluation of one's own life as a whole". It can be perceived as the assessment of life quality that gives someone a pleasure. Therefore, life satisfaction is a key indicator of mental health and it is positively related to the entire spectrum of life (Proctor et al., 2017). People who are able to achieve life satisfaction will have a healthy mentality and feel happy in establishing social relations.

Life satisfaction is categorized in income, family, and work satisfactions (Chitchai et al., 2018). Boes and Winkelmann (2010) stated that the level of income significantly reduces life dissatisfaction. Evans and Kelley (2004) showed that in Australia, people having a family feel more satisfied than a divorce. Whereas Aydintan and Koc (2016) figured teachers in Turkey have high life satisfaction with their profession.

In Islam life satisfaction must be sought in a balance manner between the material and spiritual aspects. Muslim economists call it as "falah", that is the happiness of living in this world and the hereafter. Al-Quran al-Karim affirms: "And look for what Allah has given you (happiness) of the afterlife, and do not forget your part of worldly (favor) ..." Q.S. al-Qashash [28]: 77.

For this reason, Hoetoro (2018) asserted that homo economicus should be transformed into homo Islamicus which is characterized according to some criteria. First, Siddiqi (1992) stated that homo economicus has to respect for logical economic choices, altruistic actions and social harmony. Second is that economic activities need to be worldly life and the hereafter
The Relationship between Love of Money 
IQTISHADIA

13,1

42

oriented. According to Kahf (1992) that every muslim has been obligated to perform ativities in life for obtaining Allah's bounty in this worldly life and the hereafter. In Islam there is no secularization. Third, muslim's attitudes have to meet the norms and rules set by Islamic law. Khan (1992) highlighted that Islamic law is essential in guiding the life of muslim. Fourth is prioritizing the fulfillment of desires based on maqashid al-shariat. Every aspect in life such as behavior and daily activities must be intended to achieve the objectives of shariat. Fifth is utilizing resources efficiently. Although Allah has provided ulimitted resources for the life of human being but He commanded to use it properly and efficiently. And sixth is efforts to reach falah; namely the happiness of life in this world and the hereafter.

\section{RESEARCH METHOD}

This research is inteded to find the relationship between LOM, Islamic religiosity, and life satisfaction, and the mediating effect of hedonic behavior. To achieve this objective, the research is contextualized to consumers who shop at one of the largest department stores in Malang. The 99 respondents were obtained by accidental sampling from consumers who physically behave as Muslims. The data collected from the questionnaires which are distributed in November 2019 were analyzed by Smart-PLS version 3.2.8. The respondents were expected to answer $1=$ strongly disagree, $2=$ disagre, 3 = neutral, $4=$ agree, and $5=$ strongly agree.

The proposed model includes a description of the correlations between the four variables namely Love of Money (LOM), hedonic behavior, Islamic religiosity and life satisfaction. LOM is thought to play an important role in influencing life satisfaction; it is directly related to life satisfaction and indirectly is passed through hedonic behavior. Then, Islamic religiosity also influence life satisfaction. Figure 1 describes these relationships as follows:

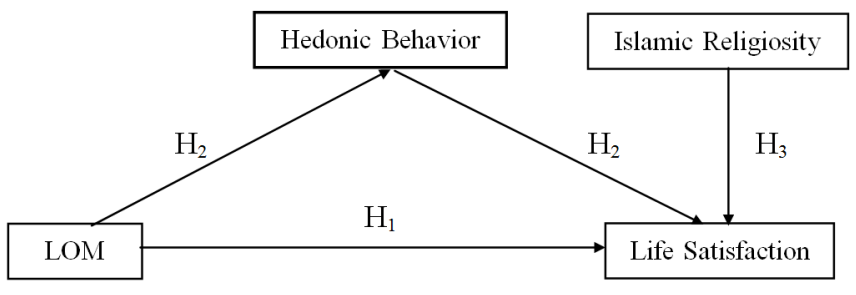

Fig. 1. The Research Model

In this model, indicators for LOM are adapted from Tang (2007), hedonic behavior from Basaran (2015), Islamic religiosity from Aliman et al. 
(2018), and life satisfaction refered to Chitchai (2018). Hence, the research framework comes up with three hypotheses as belows:

$\mathrm{H}_{1}$ : love of money directly influences life satisfaction

$\mathrm{H}_{2}$ : hedonic behavior signifacantly mediates the relationship between LOM and life satisfaction

$\mathrm{H}_{3}$ : Islamic religiosity significantly affects life satisfaction.
The Relationship between Love of Money

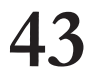

\section{RESULTS}

As displayed in Table 1, it is shown that out of the 99 respondents, the percentage of male and female were 44.44 and 55.56 per cent respectively. The majority of respondents were in the age range of 20-30 years old. Their percentage was 64.65 per cent and then was followed by 17.17 per cent of the age range of 31-40 years old. The respondents were mostly graduated from university (79.80 per cent) and 19.19 per cent finished Senior High School. Finally, around 59.59 per cent of the respondents earned income below IDR 3.000.000 and was followed by 33.33 per cent who earned income in the range of IDR 3.000.000-10.000.000. Categorically, people having income below IDR 3.000.000 are included in low income recipients.

Table 1. The Demographic Details of Respondents $(\mathrm{N}=99)$

\begin{tabular}{|c|c|c|c|c|c|}
\hline Categories & Number & (\%) & Categories & Number & $\%$ \\
\hline Gender & & & Occupation & & \\
\hline Male & 44 & 44.44 & Unemployed & 27 & 27.27 \\
\hline Female & 55 & $55 \cdot 56$ & Entrepreneur & 15 & 15.15 \\
\hline Respondent's Age & & & Private Employed & 17 & 17.17 \\
\hline$<20$ years old & 9 & 9.09 & Public Employed & 12 & 12.12 \\
\hline $20-30$ years old & 64 & 64.65 & Other & 28 & 28.29 \\
\hline $31-40$ years old & 17 & 17.17 & Income per Month (IDR) & & \\
\hline $41-50$ years old & 7 & 7.07 & $<3.000 .000$ & 59 & 59.59 \\
\hline$>50$ years old & 2 & 2.02 & $3.000 .000-10.000 .000$ & 33 & 33.33 \\
\hline Education Level & & & $10.000 .500-17.000 .000$ & - & - \\
\hline Elementary School & - & - & $17.000 .500-24.000 .000$ & 4 & 4.04 \\
\hline Junior High School & 1 & 1.01 & $24.000 .500-31.000 .000$ & 2 & 2.02 \\
\hline Senior High School & 19 & 19.19 & $>32.000 .000$ & 1 & 1.01 \\
\hline University & 79 & 79.80 & & & \\
\hline
\end{tabular}

Table 2 displays the values of Cronbach's alpha, Composite Reliability (CR), and Average Variance Extracted (AVE) which satisfied the requirenment 
IQTISHADIA

13,1

as suggested by Hair et al. (2014). According to them that the cut off for Cronbach's Alpha value is 0.6, Composite Reliability is 0.6, and AVE is 0.5.

Table 2. Loading Factors, CR and AVE of Constructs

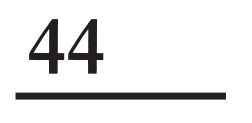

\begin{tabular}{|c|c|c|c|c|c|c|c|c|c|}
\hline Indicators & $\alpha^{*}$ & CR & AVE & $\lambda^{*}$ & Indicators & $a^{*}$ & CR & AVE & $\lambda^{*}$ \\
\hline LOM & 0.853 & 0.888 & 0.534 & & Ethics & 0.810 & 0.888 & 0.728 & \\
\hline Motivation & 0.841 & 0.894 & 0.679 & & IR4 & & & & 0.754 \\
\hline Lom1 & & & & 0.814 & IR5 & & & & 0.894 \\
\hline Lom2 & & & & 0.895 & IR6 & & & & 0.903 \\
\hline Lom3 & & & & 0.833 & Hedonic Behavior & 0.732 & 0.824 & 0.539 & \\
\hline Lom6 & & & & 0.747 & HB1 & & & & 0.758 \\
\hline Perception & 0.786 & 0.875 & 0.700 & & HB6 & & & & 0.731 \\
\hline Lom7 & & & & 0.847 & $\mathrm{HB} 7$ & & & & 0.728 \\
\hline Lom8 & & & & 0.790 & HB8 & & & & 0.717 \\
\hline Lom9 & & & & 0.872 & Life Satisfaction & 0.701 & 0.819 & 0.536 & \\
\hline Islamic Religiosity & 0.878 & 0.909 & 0.625 & & Income Satisfaction & 0.788 & 0.904 & 0.825 & \\
\hline Belief & 0.741 & 0.853 & 0.658 & & LS1 & & & & 0.907 \\
\hline IR1 & & & & 0.814 & LS2 & & & & 0.910 \\
\hline IR2 & & & & 0.808 & Social Relations & 0.648 & 0.846 & 0.734 & \\
\hline \multirow[t]{2}{*}{ IR3 } & & & & 0.812 & LS8 & & & & 0.911 \\
\hline & & & & & LS9 & & & & 0.799 \\
\hline
\end{tabular}

$*=\alpha$ is Cronbach's Alpha and $\lambda$ is Loading Factors of Indicators

After getting these values, the calculation of hypotheses is presented in Table 3 and Figure 2. It shows that LOM significantly influences hedonic behavior $(\beta=0.417 ; \rho$-value $=0.000)$ and Islamic religiosity contributes to life satisfaction $(\beta=0.290 ; \rho$-value $=0.003)$. Hence, hypothesis $\mathrm{H}_{3}$ is supported. The result also shows that LOM affects hedonic behavior.

However, hedonic behavior does not mediate the relationship between LOM and life satis-faction. People might percieve that they will obtain satisfaction if they consume much and enjoy the pleasure in shopping. Factually, this perception does not happen in reality which means that hypothesis $\mathrm{H}_{2}$ is not accepted. In the same time, LOM does not influence life satisfaction directly, hence, hypothesis $\mathrm{H}_{1}$ is not supported.

Table 3. Hypotheses Testing

\begin{tabular}{lrrrl}
\hline \multicolumn{1}{c}{ Category } & $\beta$ & Mean & SD & P-values \\
\hline LOM $\rightarrow$ Life Satisfaction & -0.127 & -0.126 & 0.106 & 0.234 \\
$\mathrm{LOM} \rightarrow$ Hedonic Behavior & 0.417 & 0.433 & 0.073 & $0.000^{*}$ \\
$\mathrm{LOM} \rightarrow$ Hedonic Behavior $\rightarrow$ Life Satisfaction & 0.038 & 0.036 & 0.044 & 0.390 \\
Islamic Religiosity $\rightarrow$ Life Satisfaction & 0.290 & 0.288 & 0.097 & $0.003^{*}$ \\
\end{tabular}

*: significant at 0.01 level 


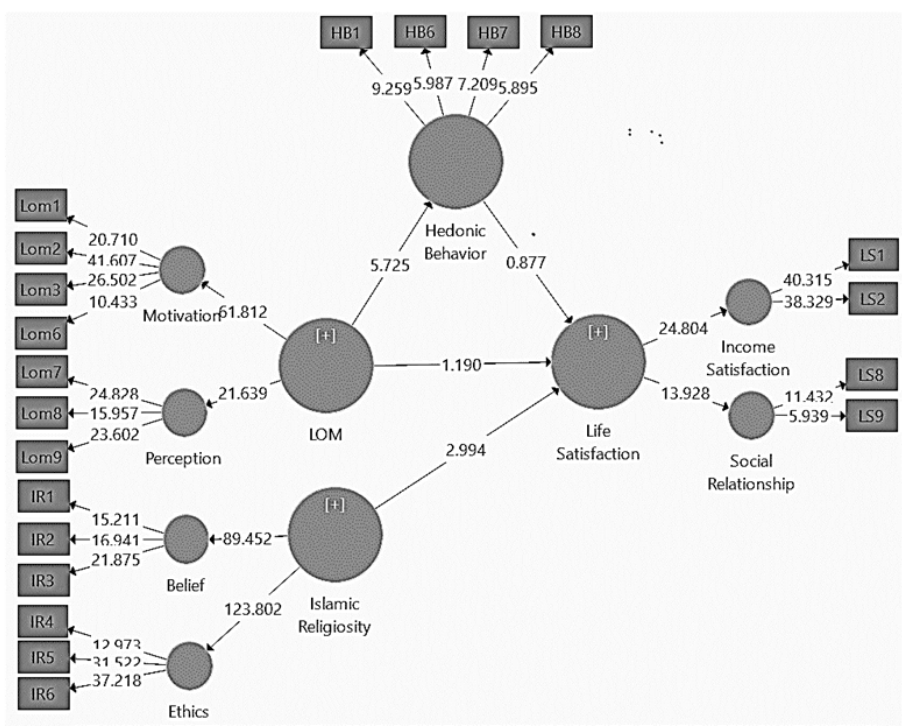

The Relationship

between Love of

Money

Fig. 2. The Model

\section{DISCUSSION}

This study has proved that for a muslim life satisfaction is not only related to something that materially satisfy all his desire in life. There is another aspect that more strengthens the taste of life satisfaction namely spiritual bliss. In spending behavior, for instance, LOM indeed affects muslim consumers to hedonic behavior. When they go to the mall, they can enjoy every spending. According to Patel and Sharma (2009) there have been two motives that directs people to shop in mall, namely utilitarian and hedonic motives. In terms of hedonic consumption, they identified six motivations which related to shopping enjoyment, gratification shopping, idea shopping, shopping for aesthetic ambience, roll shopping, and social shopping. This research supported the same things, especially related to shopping enjoyment.

This enjoyment in shopping, however, does not provide them life satisfaction. In fact, hedonic behavior does not intermediate the relationship between LOM and life satisfaction. The presence of Islamic religiosity then influences muslim customers in pursuing happiness that makes them satisfied both materially and spiritually.

Some people behave hedonically because they want to pursue something that can satisfy their life. For instance, Sholeh (2017) proved that hedonic lifestyle among psychology students of Indonesia Islamic University has a close relationship with their satisfaction in lifestyle. However, this research is not in line with Sholeh's findings. It does not means that shopping at mall always relate to search life satisfaction. 
IQTISHADIA

13,1

46

LOM clearly affects the inclination to behave hedonically. Having more money drives people to search everything that gives them a pleasure. According to Carter (2014), the act of spending money is an emotional decision. It contains some hedonic consequences that can last far into the future. Tong et al. (2013) proved that money priming in spending shows various behaviors. Consumers in the money priming condition are more likely to choose utilitarian over hedonic spending, but not when primed with credit cards. Meanwhile, Yu et al. (2018) stated that hedonic shopping values are mainly influenced by entertainment construct.

This study in line with all these researches. Shooping at the mall or department store, for example, can make consumers to enjoy the atmosphere of shopping center. There are a lot of entertainment desires that attract consumers' interest to shop. Consequently, this activity raises the sense of addiction so that shopping at the mall is used as a means to please them. Along with rising incomes, hedonic behavior has now become the lifestyle of modern society. Along to fulfil to daily needs, people shop in department store is intended to seek pleasures and enjoyments.

However, this hedonic behavior does not mean that it will influence to obtain satisfaction in life. Theoretically, according to microeconomics that an individual will be motivated to maximize his utility. In consumer behavior, the maximization of utility becomes a main motive for consumer. Nevertheless, this study does not prove this proposition. The results support Martin et al. (2010) although they have differentiated between pleasure and life satisfaction. According to them, that hedonic behavior will influence a pleasure, not life satisfaction.

Islamic relgiositybecomes an important factor for getting life satisfaction and happiness. It affects customers to spend their money proportionally between material and spiritual enjoyment. Islamic believe and ethics guided Muslim customers to accept willingly their incomes as a bounty from Allah. Therefore, consumption patterns which are represented in the form of shopping activities in department store simply give Muslim customers in enjoying shopping experience. These activities might drive them to behave hedonically although do not satisfy their life.

The presence of Islamic religiosity that ethically accompanys Muslim consumption then gives a main effect in obtaining life satisfaction. For Muslim customers, shopping activities that are in line with Islamic religiosity can hold them from hedonic behaviors. Accordingly, this attitude drive them 
to get life satisfaction, especially in income satisfaction and social relations. In terms of Islamic economics, this is called as falah namely the happiness in worldly life and in the hereafter.

\section{CONCLUSION}

Today, LOM becomes a main driver for people to consump much and enjoy the pleasure. In the context of people who spend their money for shopping, LOM moves them to shop at a mall or department store in order to satisfy their appetite, recreation and other behaviors that delight their desire. Selfenjoyment is likely be the lifestyle of modern society. This study revealed that Muslim customers at The Biggest Department Store in Malang city enjoy the shopping due to a driving force of LOM. Their objective is to obtain the happiness which is represented by life satisfaction. In this regards, life satisfaction is expressed in income satisfaction and social relationships.

The findings, however, show that LOM simply influences hedonic behavior. Money might directs Muslim customers to behave hedonically when they shop at huge market places. However, this hedonic behavior factually does not affect the achievement of life satisfaction. It means that for Muslim customers LOM does not give them a happiness or satisfaction in life.

Life satisfaction might be achieved if Muslim customers accompany the habits of shopping and consumption with values and ethics. This research proves that Islamic religiosity contributes to life satisfaction. In this regards, Islamic religiosity provides a Muslim the faith system to Allah and ethics structure that have to be referred as akhlak or behavior reference. As Such, Islamic religiosity guides Muslim customers to hold their desire in shopping or consumption hedonically.

In general, since Islam emphasize moderation in life, consumption activities viewed from Muslim perspective must be adjusted to this code of conduct. A Muslim should behave in line with Islamic belief and ethically make it as the guidance of life. Based on this, all daily activi-ties such as consumption will able to get life satisfaction namely the happiness in worldly life and the hereafter.

\section{LIMITATION}

This research reveals the efforts of Muslim customers in order to balance their consumption both materially and spiritually. The results prove that LOM can indeed drive a Muslim to behave hedonically but it does not affect to get life
The Relationship between Love of Money 
IQTISHADIA

13,1

48

satisfaction. When this behavior is accompanied by Islamic religiosity he accordingly can satisfy his life. As such, this study theoritically impilcate that consumer behavior in Islamic perspective is not only to maximize utility but it is intended to obtain life satisfaction (happiness).

However, there are two limitations in this research. First, most of respondents that are imployed in this study have the low level of income. It might cause an ambiguity in shopping pattern wheter Muslim customers shopp in order to fulfil their needs or to satisfy self enjoyment. And second, the research only focuses to consumption behavior in shopping. It does not cover on how Islamic religiosity affects the attainment of life satisfaction in general.

\section{References}

Abdullah, N and Majid, M. (2003). The Influence of Religiosity, Income, and Consumption on Saving Behavior: The Case of International Islamic University Malaysia (IIUM). Iqtisad Journal of Islamic Economics. Vol. 4 No. 1, pp. 37-55.

Abou-Youssef, M., Abou-Aish, W.A.E, and El-Bassiouny. (2011). Measuring Islamic-Driven Buyer Behavioral Implications: A Proposed MarketMinded Religiosity Scale. Journal of American Science. 7(8).

Akande, A. (2006). The Love of Money and Pay Level Satisfaction: Measurement and Functional Equivalence in 29 Geopolitical Entities around the World. Management and Organization Review 2:3 423452.

Alam, S.S., Mohd, R and Hisham, B. (2011). Is religiosity an important determinant on muslim consumer behavior in Malaysia? Journal of Islamic Marketing. Vol. 2 No. 1, pp. 83-96.

Aliman, N. K., Ariffin, Z.Z., and Hashim, S.M. (2011). Religiosity Commitment and Decision Making Styles among Generation Y Muslim Consumers in Malaysia. International Journal of Academic Research in Business and Social Sciences. Vol. 8 No. 1, pp. 554-576.

Basaran, U and Buyukyilmaz, O. (2015). The Effects of Utilitarian and Hedonic Values on Young Consumer's Satisfaction and Behavioral Intensions. Eurasian Journal of Business and Economics 8(16): 1-18.

Borges, G., Mondini, V., Domingues, M.J., and Lavarda, C.E. (2016). Identification of Items Used in Scales to Measure Hedonism. International Journal of Marketing, Communi-cation, and New Media. Vol. 4 No. 7, pp. 30-45. 
Carter, T.J. (2014). “The Psychological Science of Spending Money”. In E. Bijleveld and H. Aarts (eds.). The Psychological Science of Money. Springer Science+Business Media. New York.

Chitchai, N., Senasu, K and Sakworawich, A. (2018). The moderating effect of love of money on relationship between socioeconomic status and happiness. Kasetsart Journal of Social Sciences xxx: 1-9.

Dasti, R and Sitwat, A. (2014). Development of Multidimensional Measure of Islamic Spirituality. Journal of Muslim Mental Health. Volume 8 Issue 2.

Durvasula, S and Lysonski, S. (2010). Money, money, money - how do attitudes towards money impact vanity and materialism? - the case of young Chinese consumers. Journal of Consumer Marketing. Vol. 27 No. 2, pp. 169-179.

Faruqi, Y. M. (2007). Islamic view of nature and values: Could these be the answer to building bridges between modern science and Islamic science. International Education Journal 8(2): 461-469.

Firat, A., Kutucuoglu, K. Y., Saltik, I. A and Tuncel, O. (2013). Consumption, Consumer Culture and Consumer Society. Journal of Community Positive Practices, XIII (1): 182-203.

Frakt, A and Piper, M. (2014). Microeconomics Made Simple. Simple Subjects, LLC.

Gasiorowska, A and Helka, A. M. (2012). Psychological consequences of money and money attitudes in dictator game. Polish Psychological Bulletin. Vol. 43(1), pp. 20-26.

Gultekin, B and Ozer, L. (2014). The Influence of Hedonic Motives and Browsing on Impulse Buying. Journal of Economics and Behavioral Studies. Vol. 4 No. 3, pp. 180-189.

Hair Jr, Joe F., Sarstedt, M., Hopkins, L., and Kuppelwieser, V.G. (2014). Partial least squares structural equation modeling (PLS-SEM): An emerging tool in business research. European Business Review Vol. 26 No. 2: 106-121.

Hassan, R. (2005). On Being Religious: Pattern of Religious Commitment in Muslim Societies. The Working Paper No. 80. Institute of Defense and Strategic Studies. Singapore.

Hoetoro, A. (2018). Ekonomi Mikro Islam: Pendekatan Integratif. Malang. UB-Press.

Joshanloo, M. (2013). A Comparison of Western and Islamic Conceptions of Happiness. Journal of Happiness Study 14: 1857-1874.
The Relationship between Love of Money 
IQTISHADIA

13,1

Kainulainen, S., Saari, J., and Veenhoven, R. (2018). Life Satisfaction is more a Matter of Feeling-Well than having What-You-Want: Tests of Veenhoven's Theory. International Journal of Happiness and Development. Vol. 4 No. 3, pp. 209-235.

Kaul, S. (2007). Hedonism and Culture: Impact on Shopping Behaviour A Research Agenda. Vikalpa. Vol. 32 No. 3, pp. 81-89.

Khraim, H.: Measuring Religiosity in Consumer Research from Islamic Perspective. (2010). International Journal of Marketing Studies. Vol. 2 No. 2.

Kirchgassner, G. (2014). On self-interest and greed. Journal of Business Economics. 84: 1191-1209.

Krugman, P and Wells, R. (2008). Microeconomics. New York. World Publishers.

Ksendzova, M., Iyer, R., Hill, G., Wojcik, S. P., and Howell, R. T. (2015). The portrait of a Hedonist: The personality and ethic behind the value and maladaptive pursuit of pleasure. Personality and Individual Differences 79, pp. 68-74.

Lamido, A. A. (2016). Maqasid al-Shariah as a Framework of Economic Development Theorization. International Journal of Islamic Economics and Finance Studies. Vol. 2 No. 1. 27-49.

Mahdzan, N.S., Zainudin, R., Che Hashim, R and Sulaiman, N.A. (2017). Islamic Religiosity and portfolio allocation: the Malaysian context. International Journal of Islamic and Middle Eastern Finance and Management. Vol. 10 No. 3: 434-452.

Martin, J.S., Perles, F and Canto, J.M. (2010). Life Satisfaction and Perception of Happiness among University Students. The Spanish Journal of Psychology. Vol. 13 No. 2, pp. 617-628.

Mondal,A.L.(2016). Mill's Critique ofBentham's Utilitarianism.International Journal of Philosophy Study. Volume 4, pp. 13-21.

Olufadi, Y. (2016). Muslim Daily Religiosity Assessment Scale (MUDRAS): A New Instrument for Muslim Religiosity Research and Practice. Psychology of Religion and Spirituality.

Soper, K. (2017). A New Hedonism A Post-Consumerism Vision. TRANSFORMATIONS: Systemic Challenges and Solutions in $21^{\text {st }}$ Century. America. 
Spiengers, N. (2019). The Multidimensional Impact of Islamic Religiosity on Ethno-religious Social Tolerance in the Middle East and North Africa. Social Forces 97(4).

Tang, T. Li-Ping and Liu, H. (2012). Love of Money and Unethical Behavior Intention: Does an Authentic Supervisor's Personal Integrity and Character (ASPIRE) Make a Difference? Journal of Business Ethics. Volume 107: 295-312.

Tang, T. Li-Ping and Jia-Chen, Y. (2008). Intelligent Vs. Wisdom: The Love of Money, Machiavellianism, and Unethical Behavior across College Major and Gender. Journal of Business Ethics 82: 1-26.

Tang, T. Li-Ping. (2007). Income and Quality of Life: Does the Love of Money make a Difference? Journal of Business Ethics 72: 375-393.

Tang, T. Li-Ping., Tang, D. Shin-Hsiung, and Luna-Arocas, R. (2005). Money Profiles: the love of money, attitudes, and needs. Personnel Review. Vol. 34 No. 5: 603-618.

Tang, T. Li-Ping., Tillery, K.R., Lazarevski, B and Luna-Arocas, R. (2004). The love of money and work-related: Money profiles in Macedonia. Journal of Managerial Psychology. Vol. 19 No. 5: 542-548.

Tong, L., Zheng, Y., and Zhao, P. (2013). Is money really the root of all evil? The impact of priming money on consumer choice. Springer Science+Business Media. New York.

Yener, D., Dursun, T and Oskaybas, K. (2014). Hedonism, Materialism and Consumer Boycott Participation. IIB International Refereed Academic Social Sciences Journal. Vol. 5 Issue 15, pp. 99-111.

Yilmaz, M. A and Kocoglu, D. (2018). Hedonic and Utilitarian Aspect of Traditional Retail Shopping. European Scientific Journal. Special Edition, pp. 75-84.

Yu, H., Zhang, R., and Liu, B. (2018). Analysis on Consumer's Purchase and Shopping Well-Being in Online Shopping Carnivals with Two Motivational Dimensions. Sustainability, 10, pp. 1-18.

Zubairu, U. M., Dauda, C. K., Paiko, I. I., and Sakariyau, O. B. (2017). Religiosity and Moral Competence: A Study of Malaysia's Accounting Students. Vol. 2 Issue 1, pp. 1-14.
The Relationship

between Love of Money

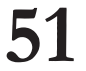


IQTISHADIA

13,1
Appendix. Items for Model Indicators

\begin{tabular}{ll}
\hline \multicolumn{1}{c}{ Indicators } & \multicolumn{1}{c}{ Items of Questions } \\
\hline LOM & \\
Motivation & \\
Lom1 & I wish that I will be a rich man \\
Lom2 & I will be happy if I rich \\
Lom3 & I always expect that I have a lot of money \\
Lom4 & I do everything for money \\
Lom5 & I always work hard to get money \\
Lom6 & I am motivated by money \\
Perception & \\
Lom7 & According to me money is good \\
Lom8 & According to me money is important \\
Lom9 & According to me money is valuable \\
HEDONIC BEHAVIOR & \\
HB1 & I always feel happy \\
HB2 & I enjoy my lifestyle \\
HB3 & \\
HB4 & I am stimulated by everything that makes me happy \\
HB5 & \\
HB6 & I enjoy shopping in mall or department store \\
HB7 & I follow the mode trends \\
HB8 & I like shopping \\
ISLAMIC RELIGIOSITY & \\
Belief & \\
IR1 & I perform all duties instructed by my religion \\
IR2 & I always learn the Holy Book \\
IR3 & I always provide sadaqah (charity) \\
Ethics & I always consume halal goods \\
IR4 & I always search permissible (halal) income \\
IR5 & I always feel that Allah watches me \\
IR6 & I adjust my attitude/ behavior with Islamic norms \\
IR7 & \\
LIFE SATISFACTION & I built close relationship with colleagues and others \\
Income Satisfaction & I am satisfied with my income \\
LS1 & I can buy goods that I like it \\
LS2 & I can save part of my income \\
LS3 & \\
LS4 & \\
Social Relationship & \\
LS5 & \\
LS6 & \\
LS7 & \\
LS8 & \\
\hline
\end{tabular}

